For citation: Amiri, H. \& Barani Beiranvand, M. (2020). Business Environment and Strengthening of the Economy: Selected Countries of Western Asia. Ekonomika regiona [Economy of region], 577-585

http://doi.org/10.17059/2020-2-18

UDC: 346,338

JEL: F20, F43, F52, F64

H. Amiri, M. Barani Beiranvand

Kharazmi University (Tehran, Iran; e-mail: Hossienamiri@gmail.com)

\title{
BUSINESS ENVIRONMENT AND STRENGTHENING OF THE ECONOMY: SELECTED COUNTRIES OF WESTERN ASIA
}

The business environment is one of the factors that affect the performance and growth of firms. The business environment is a set of conditions that affect the state of the economy. This paper examines how improvement of the business environment influences strengthening of the economy in the selected countries of western Asia (23 countries) by using panel data method for the period from 2010 to 2017. In other words, we hypothesise that the business environment positively and significantly affects strengthening of the economy in these countries. The paper aims to examine the explanatory variables of strengthening of the economy. The dependent variable is the sum of budget deficit and the facilities of financial and credit institutions to the state budget minus the tax revenue to the state budget. The independent variables are business index, good governance index, economic misery index, foreign direct investment, gross fixed capital formation, government expenditures and population growth. The research findings indicate that the business environment has a positive and significant impact on strengthening of the economy. Thus, in order to strengthen the economy in the considered countries, we suggest using some approaches facilitating the business environment, particularly for productive sectors of the economy, focused on generating productive employment.

Keywords: business environment, strengthening the economy, good governance, index of economic freedom, selected countries of Western Asia, panel data, performance of economic firms, business index, institutional conditions, regulatory conditions

\section{Introduction}

The business environment is a set of policies, legal, institutional and regulatory conditions defining business activities. Doing Business covers 12 areas of business regulation. Ten of these areas - starting a business, dealing with construction permits, getting electricity, registering property, getting loans, protecting minority investors, paying taxes, trading across borders, enforcing contracts, and resolving insolvency - are included in the ease of doing business score and ease of doing business ranking. Doing Business also measures regulations on employing workers and contracting with the government, which are not included in the ease of doing business score and ranking [25].

Considering that the business environment is one of the factors determining the economic state in each country, we can analyse the existing economic situation by studying that phenomenon. The growth and development of the economy, as well as increase in a country's economic health depend on having a suitable business environment [1]. The growth and development of the business environment is a basic and

\footnotetext{
${ }^{1}$ ( ) Amiri H., Barani Beiranvand M. Text. 2020.
}

positive step toward fostering participation of the private sector in the economy and increasing employment and production. What is more, it is one of the most important indicators for entering the host country from the perspective of foreign investors [2]. Thus, a significant part of economic growth requirements in each country depends on favourable business environment in that specific country. However, inappropriate business environment can have undesirable effects on the performance of managers in productive firms, work force, economy investors, as well as on the product and economic processes such as sales, domestic and global competition, and industrial and economic development of countries. Inappropriate business environment prevents creation of healthy economic activities and imposes a high cost on national economy. Therefore, the lack of attention to the business state can threaten the economic and national security. Explanation of the place of the business environment helps policymakers and economic planners to choose the right way to formulating policies in order to strengthen the economy. The knowledge about the business environment allows creating a statistical basis for formulating the policies aimed at economic strengthening. 
The economy is always exposed to major disruptions and shocks, including economic stagnation, currency crisis, technological gaps, etc. All these factors can influence the path and pattern of economic growth and create instability. Therefore, the economic resilience can help the country economy to prevent and confront these internal shocks [3].

Regarding the above, the improvement of the business environment that effectively promotes investment in private sector can provide the background for realizing strengthening goals of the country, productive economy and production sector. As inappropriate business environment is considered as one of the main economic problems in the studied countries of western Asia in the late years, improvement of the business environment can help to realize the goals of strengthening of the economy in these countries. Thus, in this research we study the impact of the improvement of the business environment on strengthening of the economy.

The research goal is to examine the effect of improving the business environment on the economy in the selected countries of western Asia using the panel data method for the period from 2010 to 2017.

According to the research goal, we hypothesise that improvement and expansion of the business environment has a positive and significant effect on strengthening of the economy of the selected countries of Western Asia.

To investigate this hypothesis, we designed a conceptual model of the relationship between the business environment and strengthening of the economy, and created a combined index of economic strengthening.

This research has five sections. The second section includes empirical and theoretical literature review. The third section discusses the research method. The fourth section presents the research results. The last section provides conclusion and solutions aimed at strengthening of the economy.

\section{Literature Review}

There are many studies on the place and role of the business environment in advancing the state goals and achieving economic development. Various scientists and experts in this area present the business environment as an effective factor in economic development. The business environment is a topic that has been widely discussed in the late years. In this section, we discuss some of these studies.

In order to reach general policy goals of privatization, support non-governmental sector and de- velop the business environment, it is necessary to use extensive, easy and incremental interactions in the economic sphere [4].

Improving the business environment is one of the most important and main ways of development, even in case of a small capital, as lesser government regulation and greater reliance on sovereignty of law can make employment conditions more attractive [5]. If people have access to an efficient system of ownership, they can use their stagnant capital capacity to reinforce entrepreneurial talent. Failure to comply with property rights and laws relating to the business environment can be a major obstacle to the production and accumulation of capital.

Giri (2012) investigated the interaction between business laws and regulations and entrepreneurial activities. Using the panel data method for the information obtained from 23 OECD countries in the period from 1972 to 2002, the research explored and expanded the relationship between these phenomena. The study results indicate a positive relationship between entrepreneurship and the efficiency of business laws and regulation [6].

Haidar (2012) examined the relationship between the reforms of business environment regulations and economic growth in 172 countries of the world over the period 2006-2010. The results of the research show that business environment reforms have a positive and significant correlation with the economic growth of countries. It also points out that, on average, any reform of business regulation is associated with a 0.015 percent increase in gross domestic product (GDP) growth rates [7].

Messaoud and Teheni (2014) reviewed the relationship between business environment regulations and economic growth in 162 countries in the period 2007-2011. Using ten business performance indicators and some control variables, they discovered a strong relationship between the business indicators and economic growth with exception of the overseas business and construction permits. Their findings also suggest that the mentioned policies will lead to faster growth of poor countries in order to improve business regulations [8].

Asadi and Shirazi (2014) examined economic development in the framework of economic resilience. The results show that a unique native development model is necessary for achieving both justice and economic development [9].

Jafari Samimi and Azami (2014) studied the relationship between economic empowering or decreasing fluctuations and the resistance economics in developing countries. The results of the es- 
timation of the model uncover that the increase in uncertainty in macroeconomics causes the intense increase in government costs, reducing the resistance of the economy in the considered countries [10].

Ahmadpour daryani et al (2015) studied the development of entrepreneurship and improvement of business in Iran. The research results indicate that macro-policies affecting the entrepreneurship development act as inhibitors, thus, they need improvement [11].

Solodilova et al (2016) reviewed the formation of the administrative regulation mechanisms for business entities. The results of the research show that the high cost of implementing the laws and regulations required for business create the economic basis for increasing informal relationships [12].

Alizade (2016) investigated the correlation between the business environment and investments by using descriptive-analytical method. The results of the study indicate that there is a direct and bilateral relationship between the development of the business environment and the attraction of foreign direct investment to achieve economic growth in Iran [13].

Andreeva et al (2016) examined the role of innovative entrepreneurship in the regional economy. The results show that the strategy of cooperation between different types of companies is the most appropriate strategy for the development of innovative entrepreneurship in the region [14].

Bavarsad et al (2017) illustrated that senior management support, business perspective and quality of external factors have a positive and significant relationship with organizational resource planning. There is also a positive and significant relationship between organizational resource planning and financial performance of the company [15].

Escaleras and Chiang (2017) reviewed the "financial decentralization and institutional quality on the business environment' using panel data for the period from 2004 to 2012. The results indicate that financial decentralization improves the business environment and is more effective in low-income countries [16].

Antsygina et al (2017) investigate macroeconomic determinants of the entrepreneurial activity at different business cycle phases in 4 regions of Russia during 2005-2014. The results show that entrepreneurial activity responds to changes in regional economic business environment with a lag [17].

The mentioned academic literature demonstrates that there is a variety of perspectives on the relationship of the business environment and economic development. The studies show that many factors affect the business environment and economic development, including direct foreign investment, physical capital, and employment rates. In addition to the aforementioned factors, in this research we examined other effective variables of economic growth: Index of Economic Freedom, Good Governance Index and Combined Index of economic strengthening.

\subsection{Theoretical Review}

Economic strengthening means strengthening of the economy against severe economic impulses such as oil shocks and sanctions. In order to implement the goals of economic strengthening in the intended countries, it is necessary to use of all available capacities to increase investment for improving national production. Therefore, if the domestic economy is driven by production, economic activists will be encouraged to engage in productive activities, getting away from mediation activities and other unproductive activities. It is also possible to boost production in the country by improving the business environment and attracting domestic and foreign investors. In other words, the improvement of business is necessary for implementing the goals of economic strengthening in the selected countries of western Asia. Improvement of the business environment is an essential step towards increasing investment in private sector and developing production and employment. The imposing international sanctions, economic instability, complex rules and regulations, existence of corruption, weaknesses in property rights, and other factors are the results of the absence of suitable business environment in the studied countries. Therefore, the improvement of the business environment, which effectively promotes investment in private sector in the field of production economics and manufacturing, provides the background for realizing the goals of economic strengthening in desired countries. Additionally, the economic strengthening approach includes improvement of the country business environment; therefore, the policies of economic strengthening focus on the private sector, provide economic stability, clarify the economy and prevent corruption activities.

Regarding the aforementioned issues, as the improvement of the business environment strengthens the economy, it is necessary to pay attention to the understanding of economic strengthening. Hill et al (2008) define economic strengthening as the ability of an area to recover from shocks that drive the economy out of 
growth way or eliminate its potential factor [18]. Simmie and Martin (2010) also consider economic strengthening as the resilience of a market to environmental shocks in order to develop the economic growth path, which, if necessary, will be accepted and adapted to the changing economic, social and institutional structures. Therefore, economic strengthening will preserve or restore and return to either old development path or to a new sustainable path [19].

The measures necessary for strengthening the economy can be divided into two categories. The first category is the actions that need to be taken before a momentum actually occurs, and impose the least damage on economic activities [20, 21]. These types of actions, by their nature, have a relatively wide range and include a variety of activities. The second group is the activities that must be done after the momentum has arisen to restore economic activity with the least damage to the initial balanced conditions. Such actions are mainly related to self-sacrifice, as in unfavourable post-crisis conditions, economic factors with hard work and uninterrupted efforts reduce the negative consequences of the occurred crisis and ultimately fix them.

One of the most important issues that can affect economic strengthening of the country is the business environment. In the 1990s, economic literature introduced the 'business environment' as a communication circle between microeconomics and macroeconomics [22]. Up to now, different international organizations have presented various indicators for analysing the business environment. Among these organizations are World Economic Forum organizations, the Heritage Foundation, Fraser Institute, the Global Entrepreneurship Monitoring Organization (GEM), the Global Competitiveness Index, the Human Development Index, and Labor and Social Security Institute. The most important of these is the approach of the World Bank (that is one of the noblest sponsors of privatization), which has identified indicators for measuring the business environment based on De Soto theories and techniques. Using these methods, each year the World Bank sets the ranking of the business environment of the world's countries. Due to the nature of the formation, the index of improvement or ease of business environment is a new and unique approach. The World Bank has elaborated this 'ease of doing business index'; it has been on the agenda since 2003. This index has become a relatively valid indicator for measuring the economies of the countries and has been welcomed by major economic actors and macro policy-makers [23].
One of the first research on the business environment was conducted by De Soto (2010). He analysed the business environment in several developing and developed countries [5]. De Soto has played the most important role in designing the concept of the business environment and in creating policy to remove the barriers of the private sector as the main economic development strategy of all economists. He introduced the business environment as an important factor of production. Inappropriate business environment imposes high costs on the economy and creates negative effects on the economic performance [5].

Accordingly, unlike the majority of economists, De Soto does not consider the lack of savings to be the cause of underdevelopment. Developed and developing countries differ in one aspect: most people in developing countries have property, but have no process to show their ownership and create capital. The findings showed that laws and official documents in developing countries has limited the possibility of capital accumulation and its use in productive activities. The inadequate investment and business environment in these countries have pushed a large part of the economic agents to the informal sector, while the possibility of actors' growth in informal sector is very limited [24].

\subsection{Empirical Review}

Internal and external dimensions of the business index show a general picture of the business environment for domestic and foreign investors. This sub-section examines the ease of doing business in the selected countries of western Asia. According to Figure 1, Iran is far from the United Arab Emirates considering the business environment (Emirates is one of the first five countries in terms of the business environment).

Figure 2 presents a conceptual model that has described the relationship between the business environment and the implementation of the goals of economic strengthening. The approach to strengthening of the economy can protect the national economy from internal and external attacks through the active participation of the people and lead to increasing economic growth in the long term. The knowledge of people's strength and behaviour allows planning and explaining appropriate policies necessary to overcome crises and political and economic challenges. Thus, it can reduce the negative effects of the vulnerability of external conditions to the minimum. In other words, the basis of the long-term policy of economic strengthening has been planned and developed for private sector investors of the studied 


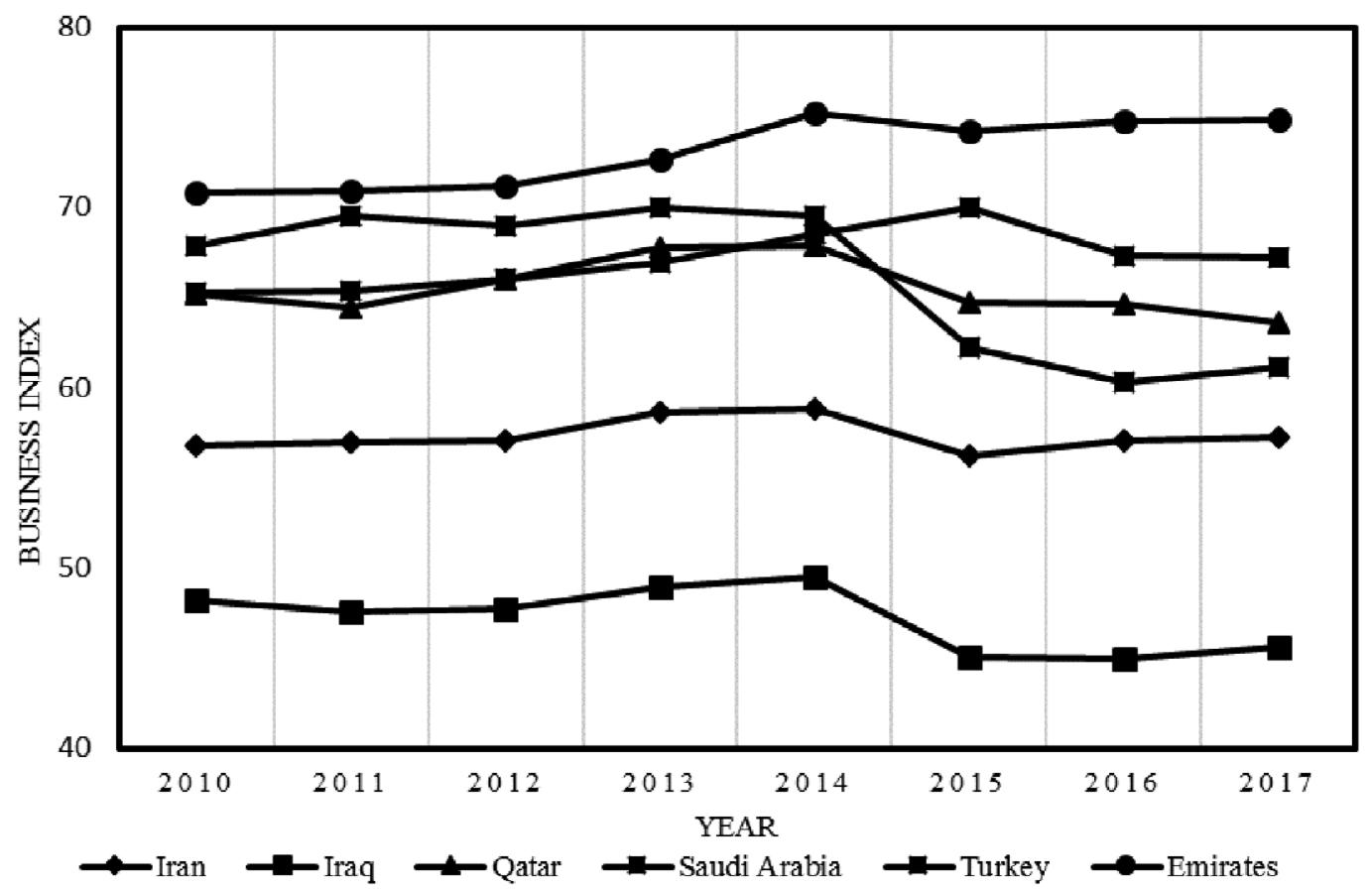

Fig. 1. Business index in the selected countries of Western Asia (source: Doing Business (2017) [25])

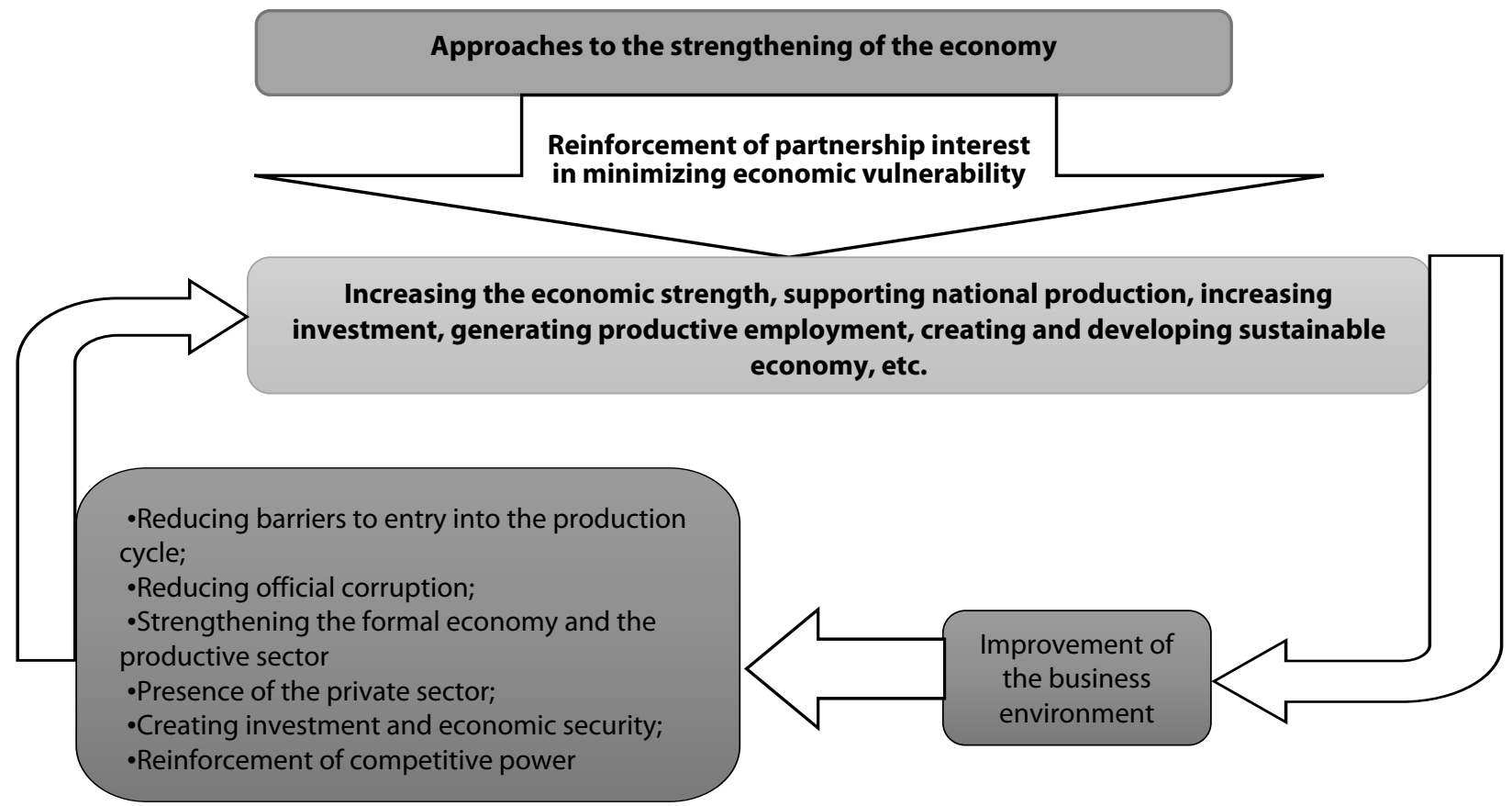

Fig. 2. Conceptual Model of the Relationship between the Ease of the Business Environment and Economic Strengthening (source: Research findings)

countries. It focuses on controlling the negative effects of political fluctuations and challenges, providing economic security and economic stability, and creating a sense of confidence.

Hence, improvement of the business environment will cause reduction of the barriers to entry production cycle, reduction of official corruption, widespread presence of the private sector, strengthening of the formal economy, strengthening of the productive sector, investment security, and the national economic security. Therefore, improvement of the business environment is necessary for implementing the goals of economic strengthening.

\section{Research Method}

In this section, we aim to link the business index with the index of economic strengthening. The index of economic strengthening is a combination of a variety of factors. 
The dependent variable is the sum of budget deficit and the facilities of financial and credit institutions to the state budget minus the tax revenue to the state budget.

In the present study, we use analytical and econometric method applying the panel data methodology for the selected countries of western Asia ${ }^{1}$ in the period 2017-2010. Therefore, as the research goal is to investigate the impact of improvement of the business environment on economic strengthening, this paper identifies the factors affecting economic strengthening. For creating the model, we have chosen the variables affecting the combined index of economic strengthening: business index, index of economic freedom, good governance index, economic misery index, foreign direct investment, gross fixed capital formation, population growth, government expenditures.

The panel data method is used for integrating sectional and time series data. According to that, observations are examined using a large number of sectional variables that are often randomly selected over a given time period. In total, panel data has many advantages in comparison to the sectional data and time series data. Sectional and time series data do not consider individual heterogeneity, therefore they may give a turbulence estimate, while panel data takes these heterogeneities into account by paying attention to special individual variables. The panel data has more information, more variability, less collinearity, higher degree of freedom and more efficiency than time series and sectional data, especially since one of the coherence reduction methods is the combination of time series data and sectional data by panel data [26].

Therefore, according to the research variables, the model equals to:

$$
\begin{gathered}
E R_{i t}=\alpha_{0}+\beta_{1} B E_{i t}+\beta_{2} G F C F_{i t}+ \\
+\beta_{3} F D I_{i t}+\beta_{4} E M_{i t}+\beta_{5} G_{i t}+ \\
+\beta_{6} G P O P_{i t}+\beta_{6} E F_{i t}+\beta_{7} G G_{i t}+U_{i t},
\end{gathered}
$$

The combined index (ER) of the economic strengthening is dependent variable that is the sum of budget deficit and the facilities of financial and credit institutions to the state budget minus the tax revenue to the state budget.

Independent variables are defined as follows:

- Business Environment Index (BE) includes 10 sub-indicators.

\footnotetext{
${ }^{1}$ Afghanistan, Armenia, UAE, Georgia, Iraq, Saudi Arabia, Iran, Turkey, Tajikistan, Bahrain, Yemen, Syria, Palestine, Lebanon, Kazakhstan, Kyrgyzstan, Uzbekistan, Oman, Qatar, Pakistan, Kuwait, Azerbaijan, Jordan.
}

- Index of Economic Freedom (EF) is the average of 9 sub-indicators (property rights, absence of corruption, tax freedom, government expenditures, monetary freedom, business freedom, trade freedom, investment freedom and financial freedom).

- Good Governance Index (GG) is the average of 6 sub-indicators (criticism and accountability, political stability and lack of violence, government effectiveness, quality and way of establishing regulation, rule of law and control of corruption).

- Economic Misery Index (EM) is one of the macroeconomic indicators, which is calculated in important country statistics. This indicator comes from the sum of unemployment rate and inflation rate of a country.

- Foreign Direct Investment (FDI) is a percentage of gross domestic product (GDP).

- Gross Fixed Capital Formation (GFCF) is a percentage of GDP.

- Government Expenditures (G) includes all government expenditures as a percentage of GDP.

- Population Growth (GPOP) includes all people in the country as a percentage of GDP.

The data on variables is adopted from the World Bank (2017), the Heritage Foundation (2017), Fraser Institute (2017) and Doing Business (2017) database [27, 28, 29, 25].

\section{Results and Discussion}

For initial data analysis, in Table 1 we present descriptive statistics of the research variables that can be assessed in multivariate linear regression of combined data.

The descriptive statistics include mean, standard deviation, maximum and minimum. Also, for assessing the normality of variables' distribution, we used the Jarque-Bera statistic.

Before estimating the model, it is necessary to perform unit root tests. We used the Levin-LinChu stability test to examine the unit root, applying the combined data. Based on this test, $P$-Value was less than 0.05 , all of the research variables are stationary. It means that the mean and variance of the variables, as well as covariance of the variables over several years were fixed. As a result, the use of these variables in the model does not result in false regression. The results of the survey in the Table 2 represent the stationary of all variables.

In order to estimate the model, the type of model has to be identified. There are various tests for this purpose. The most common are the Chow test to identify whether it is the pooled data model or the panel data model, and the Hausman test to compare fixed effects model and random effects model. For estimating the desired function and 
Descriptive statistics of research variables

\begin{tabular}{|c|c|c|c|c|c|c|c|c|c|}
\hline ER & BE & GG & EF & GFCF & G & EM & FDI & GPOP & Variable/ Statistics \\
\hline 2.09 & 64.19 & -2.35 & 62.02 & 24.72 & 13.78 & 14.49 & 1.45 & 81.8 & Average \\
\hline 9.63 & 82.09 & 2.12 & 77.70 & 33.42 & 21.52 & 49.66 & 6.43 & 191.87 & Maximum \\
\hline-0.32 & 52.33 & -6.37 & 40.30 & 12.52 & 9.73 & 0.86 & -0.36 & 30.90 & Minimum \\
\hline 2.25 & 6.62 & 2.53 & 8.62 & 4.93 & 3.26 & 8.53 & 1.61 & 35.15 & Standard deviation \\
\hline 34.73 & 5.73 & 3.96 & 8.14 & 5.61 & 5.66 & 36.87 & 27.32 & 7.95 & Jarque-Bera \\
$(0.00)$ & $(0.05)$ & $(0.13)$ & $(0.01)$ & $(0.06)$ & $(0.05)$ & $(0.00)$ & $(0.00)$ & $(0.01)$ & \\
\hline
\end{tabular}

Note: Critical value between parentheses.

Source: Research calculations.

Table 2

\section{Results of unit root tests}

\begin{tabular}{|c|c|}
\hline Dickey-Fuller statistics & Variable \\
\hline$-14.50(0.00)$ & ER \\
\hline$-2.05(0.01)$ & BE \\
\hline$-5.68(0.00)$ & GG \\
\hline$-6.36(0.00)$ & EF \\
\hline$-7.87(0.00)$ & GFCF \\
\hline$-3.99(0.00)$ & G \\
\hline$-7.23(0.00)$ & EM \\
\hline$-6.24(0.00)$ & FDI \\
\hline$-2.85(0.00)$ & GPOP \\
\hline
\end{tabular}

Note: Critical value between parentheses.

Source: Research calculations.

The results of the estimation of the model

\begin{tabular}{|c|l|}
\hline coefficients & \multicolumn{1}{|c|}{ Variable } \\
\hline $0.09(0.00)$ & Business Environment Index (BE) \\
\hline$-0.09(0.32)$ & Good Governance Index (GG) \\
\hline$-0.05(0.06)$ & Index of Economic Freedom (EF) \\
\hline$-0.23(0.00)$ & Government Expenditures (G) \\
\hline $0.06(0.10)$ & $\begin{array}{l}\text { The growth of Gross Fixed Capital } \\
\text { Formation (GFCF) }\end{array}$ \\
\hline$-0.03(0.33)$ & Economic Misery Index \\
\hline$-0.33(0.01)$ & Foreign Direct Investment (FDI) \\
\hline $0.66(0.00)$ & Population Growth (GPOP) \\
\hline
\end{tabular}

Note: Critical value in parentheses.

Source: Research calculations.

choosing which one is better, the Chow or F-Limer test is applied. If the statistic's probability is less than the $5 \%$ level, the use of the panel model is confirmed; otherwise, the pooled model will be used.

Given that the value of the F-test statistic (59.16) is greater than the critical quantity (the probability value is less than 0.05 ), the null hypothesis is rejected. Thus, we accept the other hypothesis that states it is appropriate to use the panel data.

Therefore, it is necessary to perform the Hausman test. This test can be used to choose between fixed method and random method. The value of the Hausman test statistic (25.22) is greater than the critical quantity (in other words, the probability value is less than 0.05 ), so the null hypothesis (the use of random effects) is rejected. This means that there is a correlation between the components of the disturbing and the explanatory variables. Therefore, the model is constructed using fixed effects.

Table 3 shows that we estimated the model with proper fixed effect. After selecting and determining the type of model, we explain the results of the estimation of the model.

The results show that the business environment index (BE) has a positive and significant effect on the index of economic strengthening. Therefore, in the selected countries of western Asia, the improvement of the business environment leads to strengthening of the economy, while institutional indicators such as good governance index have no significant effect on ER. However, the index of economic freedom (EF) has a negative and significant effect on ER. Thus, it can be concluded that the economic freedom has not been well implemented in the studied countries. Consequently, these countries lack in security, economic stability, rule of law, quality regulation, business freedom, as well as monetary, financial, commercial and investment freedom, meaning that their economy is weakened. At the same time, such macroeconomic indicator as the growth of gross fixed capital formation (GFCF) has a positive and significant effect on ER, while Foreign Direct Investment (FDI) has a negative and significant effect. In other words, in the studied countries, despite the limited amount of capital, due to the proper management and high capital growth, as well as replacement of domestic investment with foreign investment, the negative impact of foreign investment on economic strengthening can be seen. Government expenditures (G) have a negative and significant relationship with ER, meaning that in the considered countries, the governments focus on current expenditures instead of development expenditures, causing damage to economic strengthening. The economic misery index has no significant effect on ER. Population Growth 
(GPOP) has a positive and significant correlation with ER, so increase in the population (human capital) increases economic strengthening.

\section{Conclusion}

The present study focuses on explaining the effect of improving the business environment on economic strengthening in the selected countries of western Asia using the panel data method in the period from 2010 to 2017.

The business environment has a significant impact on the whole economy. Therefore, it is necessary to identify the causes of unfavourable business environment in the selected countries and solve this economic problem. In this research, we tried to explain the conceptual model, which is based on the relationship between the business environment and economic strengthening.

The results of this study indicate that the business index has a positive effect on the combined index of economic strengthening, while the institutional variable "good governance index" haw no significant effect on ER. Index of economic freedom negatively affects the index of economic strengthening.

The macroeconomic variables (gross fixed capital formation) have a positive and significant effect, while current government expenditures and direct foreign investment have a negative and significant effect on ER. Population growth has a positive and significant effect on ER, even though economic misery index does not significantly affect the index of economic strengthening.

Therefore, based on the research findings and the existing economic defects and weaknesses, we tried to provide solutions aimed at eliminating the defects and creating conditions for strengthening of the economy.

According to the results of this study, which pointed the positive effect of the business index on the combined index of economic strengthening, we can conclude that in the selected countries of western Asia the improvement of the business index would also improve the strengthening of the economy. So, improving their business environment the considered countries move toward economic strengthening. Therefore, in order to strengthen the economy, we would recommend to:

- Facilitate the business environment, especially for the productive sectors (industrial and agricultural);

- Strengthen the role and contribution of labour force and innovation instead of financial and commercial capital;

- Focus on generating productive employment in economic programs;

- Create policies and effective measures to drive capital toward productive activities and increase the share of industry and agriculture in capital formation of the country;

- Eliminate rents at the macro level;

- Obtain tax from macro incomes of the unproductive sectors;

- Restore and restructure the country's institutions and economic structures to support productive sectors and economic employment;

- Create sustainable and productive employment;

- Support productive sectors and productive employment.

\section{References}

1. Boroumand, S. (2008). Economic security in Iran and several selected countries (Comparative Study). Iran, Tehran: Majlis Research Center Publishing, 156.

2. Bakhtiari, S. \& Shayesteh, A. (2012). اب بختنم ىاهرشى رد ىداصتقا دشر رب راك و بسك ىاضف دوبهب رىثأت ىسررب [The effect of improving business environment on economic growth in selected countries with emphasis on Iran]. عل دام داصات [Financial Economics], 6(19), 175-204. (In Persian.)

3. Martin, R. \& Sunley, P. (2015). On the notion of regional economic resilience: conceptualization and explanation. Journal of Economic Geography, 15(1), 1-42.

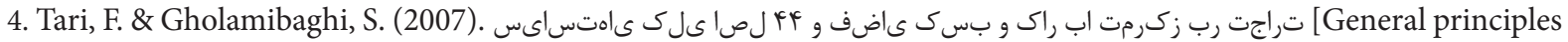


Persian.)

5. De Soto, J. H. (2010). Socialism, economic calculation and entrepreneurship. USA, Massachusetts: Edward Elgar Publishing, 320.

6. Giri, S. (2012). Business regulation and red tape in the entrepreneurial economy. Journal of Exclusive Management Science, 1(10), 1-12.

7. Haidar, J. I. (2012). The impact of business regulatory reforms on economic growth. Journal of the Japanese and international economies, 26(3), 285-307.

8. Messaoud, B. \& Teheni, Z. E. G. (2014). Business regulations and economic growth: What can be explained? International Strategic Management Review, 2(2), 69-78.



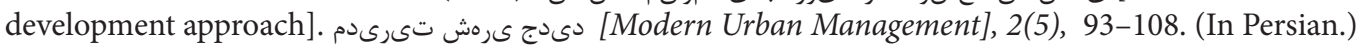


10. Jafari Samimi, A. \& Azami, K. (2014). لاح رد ىاهروشى رد ىتمواقم داصتقا دربهار رد ىداصتقا عزاسدنمناوت شقن


ع [Financial Economics], 8(28), 107-120. (In Persian.)

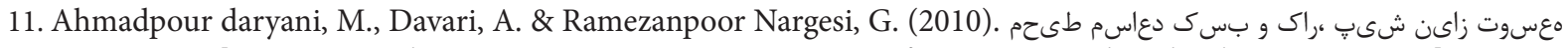

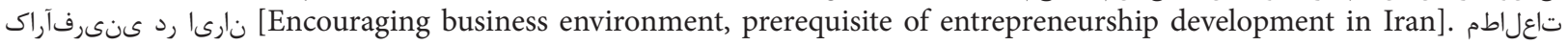
[لوحت و دوبهب) تى ردىمد [Management Studies in Development and Evolution], 17(61), 65-89. (In Persian.)

12. Solodilova, N., Malikov, R. \& Grishin, K. (2016). Vliyanie administrativnogo regulirovaniya na effektivnost predprinimatelskoy deyatelnosti $\mathrm{v}$ regione [Development of the Tools for the Assessment of the Influence of Administrative Regulation on the Business Efficiency in the Region]. Ekonomika regiona [Economy of region], 12(4), 1001-1013. (In Russ.)

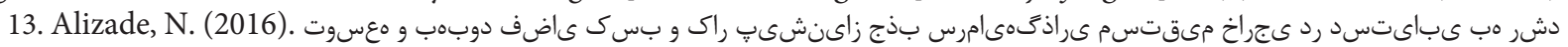
(Development and improvement of the business environment, prerequisite for attracting foreign direct investment



14. Andreeva, E. L., Simon, H., Karkh, D. A. \& Glukhikh, P. L. (2016). Innovative entrepreneurship: a source of economic growth in the region. Ekonomika regiona [Economy of region], 12(3), 899-910.

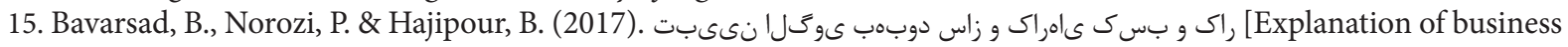

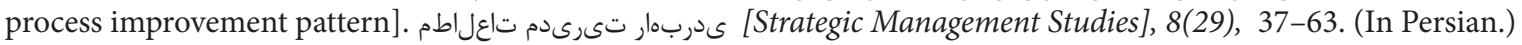

16. Escaleras, M. \& Chiang, E. P. (2017). Fiscal decentralization and institutional quality on the business environment. Economics Letters, 159, 161-163.

17. Antsygina, A., Zhukov, A. \& Sypchenko, A. (2017). Makroekonomicheskie determinanty predprinimatelskoy aktivnosti na razlichnykh fazakh biznes-tsikla: regionalnyy uroven [Macroeconomic Determinants of the Entrepreneurial Activity at Different Business Cycle Phases]. Ekonomika regiona [Economy of region], 13(4), 1095-1106. (In Russ.)

18. Hill, E., Wial, H. \& Wolman, H. (2008). Exploring regional economic resilience. Working Paper, No. 2008, 04. Institute of Urban and Regional Development, University of California. Berkeley.

19. Simmie, J. \& Martin, R. (2010). The economic resilience of regions: towards an evolutionary approach. Cambridge journal of regions, economy and society, 3(1), 27-43.

20. Bruneau, M., Chang, S. E., Eguchi, R. T., Lee, G. C., O’Rourke, T. D., Reinhorn, A. M., Shinozuka, M., Tierney, K., Wallace, W. A. \& Von Winterfeldt, D. (2003). A framework to quantitatively assess and enhance the seismic resilience of communities. Earthquake spectra, 19(4), 733-752.

21. Haimes, Y. Y. (2009). On the definition of resilience in systems. Risk Analysis, 29(4), 498-501.


G77 [The impact of business regulations and foreign direct investment on economic growth in G77 countries]. على (Financial Economics], 21(6), 81-110. (In Persian.)

23. Ahmadian, M. (2018) The situation of Iran in the World Bank business facilitation report. Iran, Tehran: Majlis Research Center Publishing, 22.


[عامتجا [Tamin-e-Ejtemaie], 7(1), 115-128. (In Persian.)

25. Doing Business 2017. A World Bank Group Flagship Report. (2017). USA, Washington: The World Bank Publishing, 356. DOI: 10.1596/978-1-4648-0948-4.

26. Baltagi, B. H. (2008). Econometric analysis of panel data. USA, New York: John Wiley \& Sons Publishing, 366.

27. World Development Indicators 2017. (2017). The World Bank Publishing, USA, Washington. Retrieved from: https:// openknowledge.worldbank.org/handle/10986/26447 (Date of access: 08.10.2019)

28. Miller, T. \& Kim, A. B. (2017). 2017 Index of economic freedom: institute for economic freedom. USA, Washington: The Heritage Foundation Publishing, 492.

29. Gwartney, J., Lawson, R. \& Hall, J. (2017). Economic freedom dataset, Economic Freedom of the World Publishing: 2017 Annual Report. Canada, Vancouver: Fraser Institute, 322. Retrieved from: https://www.fraserinstitute.org/sites/default/files/ economic-freedom-of-the-world-2017.pdf (Date of access: 08.10.2019).

\section{Authors}

Hossein Amiri - PhD in Economics, Assistant Professor, Faculty of Economics, Kharazmi University; Scopus ID: 57204681388; ORCID: 0000-0001-6876-0370 (Shahid Mofatteh Ave., Tehran, 15719-14911, Iran; e-mail: Hossienamiri@ gmail.com).

Masoumeh Barani Beiranvand - Master of Economics, Faculty of Economics, Kharazmi University (Shahid Mofatteh Ave., Tehran, 15719-14911, Iran; e-mail: masoumeh.barani1368@yahoo.com). 